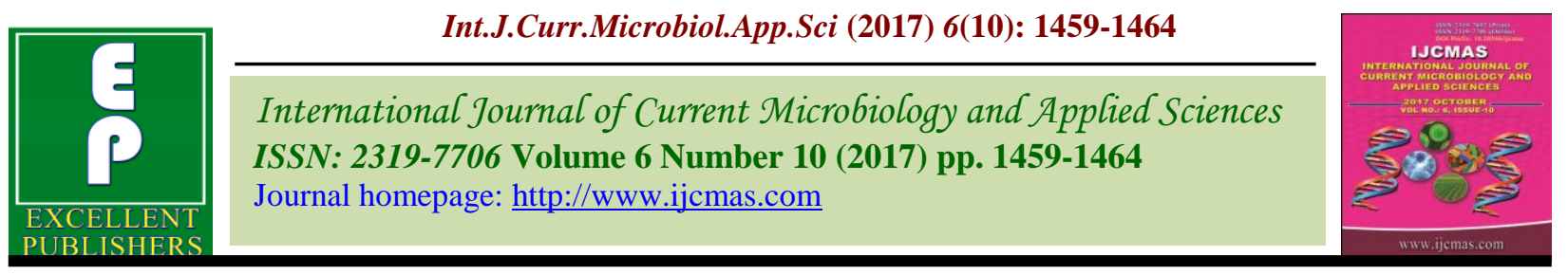

Original Research Article

https://doi.org/10.20546/ijcmas.2017.610.172

\title{
Genetic Variability and Correlation Studies in Intergeneric Hybrid Progenies of Papaya
}

\author{
D.C. Sunil Gowda ${ }^{{ }^{*}}$, C. Vasugi ${ }^{2}$ and M.R. Dinesh ${ }^{2}$ \\ ${ }^{1}$ College of Horticulture, UHS campus, Bengaluru-97, Karnataka, India \\ ${ }^{2}$ Indian Institute of Horticultural Research, Hesaraghatta-89, Karnataka, India \\ *Corresponding author
}

\section{A B S T R A C T}

\begin{tabular}{|l|}
\hline Ke y w o r d s \\
Correlation, \\
Heritability, \\
Genetic advance \\
and coefficient of \\
variation.
\end{tabular}

An investigation was carried out to estimate the genetic variability, heritability and correlation in 38 intergeneric progenies and two parents (Arka Surya and Vasconcellea cauliflora). Wide range of variability was observed in the fruit weight, fruit length, fruit width, fruit volume, cavity index, TSS, pulp thickness, vitamin C, titrable acidity, total carotenoids, lycopene, total phenols and total sugars. Phenotypic coefficient of variation was higher than the genotypic coefficient of variation for the characters studied. High heritability coupled with high genetic advance was recorded for the characters. Phenotypic correlation was found to be significant for all the traits studied, while no significance was observed for genotypic correlation with any of the traits.

\section{Introduction}

Papaya (Carica papaya L) belongs to the family Caricaceae is one of the most economically important fruit crops of the tropical and subtropical regions of the world. It is a dicotyledonous, polygamous and diploid species, with geographical origin being Southern Mexico and Costa Rica (Candolle, 1884). India stands first in the production of papaya in the world followed by Brazil, Indonesia, Nigeria, Mexico, Ethiopia and others. The area under papaya in India is estimated at 133.4 (IN '000 HA) and production at 5639.3 (IN '000 MT) (NHB, 2014). Since papaya is a highly cross pollinated and sexually propagated crop, its flowering and fruiting habit varies as a result variation exists in shape, size, quality, taste, colour and flavour of fruit. The contribution of each individual component to yield and their interrelationship must be clearly studied (Lombard et al., 1988). The genetic variability along with heritability gives reliable information of the genetic advance to be expected for selection (Burton, 1952). Heritability coupled with genetic advance aid in predicting valuable conclusion for effective phenotypic selection (Johnson et al., 1955). The present study was conducted to estimate the variability such as phenotypic variance, genotypic variance, phenotypic co-efficient of 
variation (PCV), genotypic co-efficient of variation (GCV), heritability, phenotypic, and genotypic correlation were estimated using13 quantitative traits in 38 intergeneric progenies and two parents of papaya.

\section{Materials and Methods}

The experiment was conducted at Indian Institute of Horticultural Research (IIHR), Bengaluru. A progenies of 38 intergeneric hybrid progenies of F5 generation and two parents viz., Arka Surya as female and Vasconcellea cauliflora as male were field planted during 2013 with spacing $2.1 \mathrm{~m}$ $\mathrm{x} 2.1 \mathrm{~m}$. The progenies and parents were analyzed for fruit and quality characteristics viz., fruit weight, fruit length, fruit width, fruit volume, cavity index, TSS, pulp thickness, vitamin $\mathrm{C}$, titrable acidity, total carotenoids, lycopene, total phenols and total sugars.

The standard horticultural practices were followed for the progenies and parents. The fruit quality parameters were estimated as total carotenoids and lycopene (Lichtenthaler, 1987), Total sugars (Somogyi, 1952), titrable acidity (AOAC, 2000) and ascorbic acid (AOAC, 2006). The biochemical parameters were estimated as total phenols (Singleton and Rossi, 1965) and peroxidase (Chander, 1990). Data from 13 important quantitative characters(viz., fruit weight, fruit length, fruit width, fruit volume, cavity index, TSS, pulp thickness, vitamin $\mathrm{C}$, titrable acidity, total carotenoids, lycopene, total phenols and total sugars) were analyzed for variability, heritability, genetic as per cent mean and correlation using the SPAR II computer package developed by (Ahuja et al., 2003).

\section{Results and Discussion}

The variability estimates exhibited considerable differences for all the traits studied (Table 1).
The phenotypic variance ranged from 0.001 (titrable acidity) to 29142.5 (fruit weight) and genotypic variance ranged from 0.001 (titrable acidity) to 26402 (fruit weight).

The phenotypic coefficient of variation was found to be higher than the genotypic coefficient of variation for all the characters studied indicating higher degree of environmental influence, which is an observable measure of total variability, changes with the environment. In the present study, PCV ranged from 7.197 per cent for TSS to 67.233 per cent for lycopene. High PCV was also observed for fruit weight (40.173), cavity index (58.787), fruit volume (45.342), titrable acidity (30.071), total carotenoids (24.553), and total sugars (28.599). The GCV ranged from 5.798 per cent for TSS to 66.86 per cent for lycopene.

The high GCV was also observed for fruit weight (38.238), cavity index (50.977), fruit volume (41.942), total carotenoids (24.221), and total sugars (28.373). High GCV recorded in the present study could be considered for selection. Kamalkumar (2003) observed high GCV and PCV for fruit quality characters. Dwivedi et al., (1995) reported that selection based on characters having higher PCV would be more effective in papaya. Similar works were reported by Suma (1995) and Subhadrabandhu and Nantaswatsri (1997)

The heritability values ranged from 64.9 (TSS) to 98.9 per cent (lycopene) among the progenies. All the traits recorded high heritability of $>60$ per cent. The traits fruit weight, vitamin $\mathrm{C}$, titrable acidity, total carotenoids, lycopene, total phenols and total sugars recorded the heritability value of $>90$ per cent indicating the scope for selection of these traits. Similar findings were reported for fruit weight $(90.6 \%)$, total sugars $(98.4 \%)$, total carotenoids $(97.3 \%)$, and total phenols (89.8\%) by Sudha et al., (2013), which 
confirms the findings of the present study. If the heritability of a character is high, selection for this character would be more effective as there is a close correspondence between genotypic and phenotypic (Singh, 1991). High heritability indicated less influence by the environment which might be useful to plant breeder for making effective selection.

The genetic advance as per cent mean (GAM) ranged from 9.62 per cent (TSS) to 136.96 per cent (lycopene) among the progenies. All the traits recorded high genetic advance as per cent mean (> $20 \%$ ) and the trait TSS recorded low genetic advance as per cent mean $(<10 \%)$.The traits fruit weight, fruit volume, cavity index, titrable acidity, lycopene and total sugar recorded high genetic advance as per cent mean of more than 50 per cent. High heritability coupled with high genetic advance as per cent mean has been registered for the fruit traits viz., fruit weight $(90.60 \%, 74.97 \%)$, cavity index (75.20, 91.06), pulp thickness $(74.60,29.35)$, titrable acidity $(97.40,60.31)$, vitamin C (98.30,30.95), total carotenoids $(97.30,49.21)$, lycopene $(98.90,136.96)$, total phenols (89.80,30.77) and total sugar (98.40,57.98) indicating better opportunities for selection. Similar findings were reported for fruit length, total sugars, total carotenoids, and titrable acidity by Kamalkumar (2003) and Davamani (2010), which confirms the findings of the present study. Sudha et al., 2013 observed high heritability and high genetic advance as percent of mean for most of the fruit quality and biochemical parameters.

Table.1 Phenotypic variance, genotypic variance, phenotypic coefficient of variation, genotypic coefficient of variation, heritability estimates on 13 quantitative traits

\begin{tabular}{|l|c|c|c|c|c|c|}
\hline Characters & $\begin{array}{c}\text { Phenotypic } \\
\text { variance } \\
(\mathbf{V p})\end{array}$ & $\begin{array}{c}\text { Genotypic } \\
\text { variance } \\
(\mathbf{V g})\end{array}$ & $\begin{array}{c}\text { Heritability } \\
\left(\mathbf{h}^{\mathbf{2}}\right)\end{array}$ & $\begin{array}{c}\text { Phenotypic } \\
\text { coefficient of } \\
\text { variation (\%) } \\
(\mathbf{P C V})\end{array}$ & $\begin{array}{c}\text { Genotypic } \\
\text { coefficient of } \\
\text { variation } \\
(\mathbf{G C V})\end{array}$ & $\begin{array}{c}\text { Genetic } \\
\text { advancement } \\
\text { as a \% mean } \\
\text { (GAM) }\end{array}$ \\
\hline Fruit weight & 29142.5 & 26402 & 90.60 & 40.173 & 38.238 & 74.97 \\
\hline Fruit length & 3.131 & 2.315 & 73.90 & 15.722 & 13.52 & 23.94 \\
\hline Fruit width & 1.954 & 1.708 & 87.40 & 16.55 & 15.472 & 29.79 \\
\hline Cavity index & 139.943 & 105.232 & 75.20 & 58.787 & 50.977 & 91.06 \\
\hline Fruit volume & 25241.6 & 21597.4 & 85.60 & 45.342 & 41.942 & 79.92 \\
\hline TSS & 0.707 & 0.459 & 64.90 & 7.197 & 5.798 & 9.62 \\
\hline Pulp thickness & 0.195 & 0.145 & 74.60 & 19.099 & 16.498 & 29.35 \\
\hline Vitamin C & 134.216 & 131.996 & 98.30 & 15.278 & 15.151 & 30.95 \\
\hline $\begin{array}{l}\text { Titrable } \\
\text { acidity }\end{array}$ & 0.001 & 0.001 & 97.40 & 30.071 & 29.672 & 60.31 \\
\hline $\begin{array}{l}\text { Total } \\
\text { carotenoids }\end{array}$ & 5.153 & 5.014 & 97.30 & 24.553 & 24.221 & 49.21 \\
\hline Lycopene & 67.233 & 3.016 & 98.90 & 67.233 & 66.86 & 136.96 \\
\hline Total phenols & 16.634 & 3841.76 & 89.80 & 16.634 & 15.764 & 30.77 \\
\hline Total sugars & 28.599 & 7.055 & 98.40 & 28.599 & 28.373 & 57.98 \\
\hline
\end{tabular}


Table.2 Phenotypic correlation between 13 morphological characters in papaya progenies

\begin{tabular}{|c|c|c|c|c|c|c|c|c|c|c|c|c|c|}
\hline & $\begin{array}{c}\text { Fruit } \\
\text { weight }\end{array}$ & $\begin{array}{l}\text { Fruit } \\
\text { length }\end{array}$ & $\begin{array}{l}\text { Fruit } \\
\text { width }\end{array}$ & $\begin{array}{l}\text { Cavity } \\
\text { index }\end{array}$ & $\begin{array}{c}\text { Fruit } \\
\text { volume }\end{array}$ & TSS & $\begin{array}{c}\text { Pulp } \\
\text { thickness }\end{array}$ & Vitamin C & Acidity & carotenoids & lycopene & $\begin{array}{c}\text { Total } \\
\text { phenol }\end{array}$ & $\begin{array}{l}\text { Total } \\
\text { sugar }\end{array}$ \\
\hline Fruit weight & 1.000 & 0.5961 & 0.8619 & $-0.2503^{*}$ & 0.9667 & 0.0490 & 0.7160 & -0.095 & -0.175 & 0.178 & $0.2385^{*}$ & 0.117 & 0.217 \\
\hline Fruit length & & 1.000 & $0.2745^{*}$ & -0.1159 & 0.5346 & -0.0191 & 0.3779 & -0.1067 & -0.0572 & -0.0416 & 0.0226 & 0.0165 & 0.1239 \\
\hline Fruit width & & & 1.0000 & $-0.3141^{* *}$ & 0.8463 & 0.0998 & 0.7170 & -0.0020 & $-0.2622 *$ & $0.2430 *$ & $0.2534 *$ & 0.0867 & 0.1814 \\
\hline Cavity index & & & & 1.0000 & $-0.2696 *$ & $-0.2969 * *$ & -0.6253 & $-0.3459 * *$ & 0.5140 & -0.5579 & $-0.2653^{*}$ & -0.1466 & -0.5472 \\
\hline Fruit volume & & & & & 1.0000 & 0.0275 & 0.6813 & -0.0962 & -0.1499 & 0.1494 & 0.2032 & 0.1404 & 0.1469 \\
\hline TSS & & & & & & 1.0000 & 0.2188 & 0.4471 & $-0.2459 *$ & $0.2704 *$ & $0.3093 * *$ & -0.0896 & 0.3678 \\
\hline Pulp thickness & & & & & & & 1.0000 & 0.1518 & -0.4293 & 0.3677 & $0.3288 * *$ & 0.0930 & 0.4238 \\
\hline Vitamin C & & & & & & & & 1.0000 & $-0.2593 *$ & 0.4432 & 0.2161 & $-0.2210 *$ & 0.4814 \\
\hline Acidity & & & & & & & & & 1.0000 & $-0.3518 * *$ & $-0.2446^{*}$ & -0.0216 & -0.4138 \\
\hline Carotenoids & & & & & & & & & & 1.0000 & 0.7354 & 0.0392 & 0.7466 \\
\hline Lycopene & & & & & & & & & & & 1.0000 & 0.0773 & 0.6208 \\
\hline Total phenol & & & & & & & & & & & & 1.0000 & -0.1514 \\
\hline Total sugar & & & & & & & & & & & & & 1.000 \\
\hline
\end{tabular}

Table.3 Genotypic correlation between 13 morphological characters in papaya progenies

\begin{tabular}{|c|c|c|c|c|c|c|c|c|c|c|c|c|c|}
\hline & $\begin{array}{c}\text { Fruit } \\
\text { weight }\end{array}$ & $\begin{array}{c}\text { Fruit } \\
\text { length }\end{array}$ & $\begin{array}{l}\text { Fruit } \\
\text { width }\end{array}$ & $\begin{array}{l}\text { Cavity } \\
\text { index }\end{array}$ & $\begin{array}{c}\text { Fruit } \\
\text { volume }\end{array}$ & TSS & $\begin{array}{c}\text { Pulp } \\
\text { thickness }\end{array}$ & $\begin{array}{c}\text { Vitamin } \\
\mathrm{C}\end{array}$ & Acidity & $\begin{array}{c}\text { Total } \\
\text { carotenoids }\end{array}$ & Lycopene & $\begin{array}{c}\text { Total } \\
\text { phenol }\end{array}$ & $\begin{array}{r}\text { Total } \\
\text { sugar }\end{array}$ \\
\hline Fruit weight & 1 & 0.6269 & 0.8976 & 0.3219 & 0.9965 & 0.1275 & 0.7527 & -0.0985 & -0.1912 & 0.1813 & 0.2497 & 0.124 & 0.2177 \\
\hline Fruit length & & 1 & 0.3754 & 0.1633 & 0.5683 & 0.0382 & 0.3841 & -0.1354 & -0.0539 & -0.0536 & 0.0221 & 0.0386 & 0.1197 \\
\hline Fruit width & & & 1 & 0.4283 & 0.8958 & 0.2311 & 0.8072 & 0.0083 & -0.2857 & 0.2659 & 0.2767 & 0.0714 & 0.1991 \\
\hline Cavity index & & & & 1 & 0.2797 & 0.4244 & -0.7453 & -0.4003 & 0.5935 & -0.6624 & 0.3164 & 0.1855 & -0.639 \\
\hline Fruit volume & & & & & 1 & 0.0844 & 0.6997 & -0.0957 & -0.1679 & 0.1601 & 0.2191 & 0.1635 & 0.1548 \\
\hline TSS & & & & & & 1 & 0.4432 & 0.5459 & -0.3018 & 0.3209 & 0.3747 & 0.1356 & 0.4791 \\
\hline $\begin{array}{l}\text { Pulp } \\
\text { thickness }\end{array}$ & & & & & & & 1 & 0.1761 & -0.4988 & 0.4589 & 0.4048 & 0.1332 & 0.4755 \\
\hline Vitamin C & & & & & & & & 1 & -0.2676 & 0.4554 & 0.2202 & 0.2399 & 0.4895 \\
\hline Acidity & & & & & & & & & 1 & -0.3604 & 0.2505 & 0.0128 & 0.4215 \\
\hline Carotenoids & & & & & & & & & & 1 & 0.7339 & 0.0447 & 0.762 \\
\hline Lycopene & & & & & & & & & & & 1 & 0.0874 & 0.6302 \\
\hline Total phenol & & & & & & & & & & & & 1 & 0.1528 \\
\hline Total sugar & & & & & & & & & & & & & 1 \\
\hline
\end{tabular}


High genotypic correlation coefficients indicate lesser influence of environment in the expression of character. In the present investigation the phenotypic correlation (Table 2) was found to be significant for all the traits studied, while no significance was observed for genotypic correlation (Table 3) with any of the traits. Fruit weight had negative significant correlation with cavity index and positive correlation with lycopene. Fruit length had positive significant correlations with fruit width. Fruit width had positive significant correlations with carotenoids, lycopene and significantly negative correlation with cavity index and acidity. Cavity index is negative significant correlations with fruit volume, TSS, lycopene and vitamin $\mathrm{C}$. The trait fruit volume had no significant correlation with any of the character studied. TSS had positive significant correlations with carotenoids, lycopene. Pulp thickness had positive significant correlation with lycopene at phenotypic level. Vitamin $\mathrm{C}$ had negative significant correlation with total phenols and acidity. Titrable acidity had negative significant correlations with lycopene and carotenoids at phenotypic level. The traits carotenoids, lycopene and total phenols had no significant correlation with any of the characters studied.

In papaya fruit quality traits are the most important character for selection. Being a highly cross pollinated crop, wide range of variation in quantitative and qualitative characters provides the basis for selection. Wide range of variation was observed in all the characters. Phenotypic coefficient of variation was higher than the genotype coefficient of variation for all the characters. High PCV, GCV, heritability and genetic advance were observed for fruit weight, cavity index, lycopene and fruit volume. High heritability coupled with genetic advance indicated the presence of additive genetic effects and therefore, simple directional selection would be effective for improving these characters.

\section{References}

Ahuja, S.P.K., Malhotra, V.K., Bhatia and Prasad, R., 2003. Statistical Package for Agricultural Research (SPAR-II). I.A.S.R.I., Library Avenue. New Delhi.

Association of Official Analytical Chemists 2000. In Official Methods of Analysis, $17^{\text {th }}$ edn, Titratable acidity of fruit products, 942.15

Association of Official Analytical Chemists 2006. In Official Methods of Analysis, Ascorbic acid, 967.21, 45.1.14

Burton, G.N., 1952. Quantitative inheritance in grasses. Proc. 6th International GrasslandCongress.1:277-283.

Chander, S. M., 1990. Enzymatic properties association with resistance to rust and powdery mildew in peas. Indian $J$. Hortic., 47:341-345.

Davamani, J., 2010. Evaluation of papaya (Carica papaya L.) hybrids for yield and quality traits. M.Sc. (Hort.) Thesis, Tamil Nadu Agricultural University, Coimbatore.

Dwivedi, A. K., Ghanta P. K. and Mitra, S. K., 1995. Genetic variability, heritability and genetic advance relating to some fruit characters in papaya (Carica papaya L.).South Indian Hort., 43(3\&4): 73-76.

Johnson, H.W., Robinson, H.F. and Comstock, R.E., 1955. Genotypic and phenotypic correlations in soybeans and their implication in selection. Agron. J., 47:477-483.

Kamalkumar, R., 2003. Evaluation of certain dioecious and gynodioecious hybrids of papaya (Carica papaya $\mathrm{L}$.) for yield and quality traits. M.Sc. (Hort.) Thesis. Tamil Nadu Agricultural University, Coimbatore. 
Lichtenthaler, H.K., 1987. Chlorophylls and carotenoids: Pigments of photosynthetic biomembranes. Met. Enzy, 148:350382.

Lombard, P.B., Callan, N.W., Dennis JR, F.G., Looney, N.E., Martin, G.C., Renquist, A.R. and Mielke, E.A. 1988. Towards a standardized nomenclature, procedures, values and units in determining fruit and nut tree yield performance. Hort. Sci., 23:813-817.

Singh, B.D., 1991. Principles of plant breeding, Kalyani Publishers, Ludhiana, India.

Singh, K., and Kumar, A., 2010. Genetic Variability and Correlation Studies in Papaya under Bihar Conditions. Acta Hort., 851.

Singleton, V.L., and Rossi, J.A., 1965. Acolorimetry of total phenolics with phosphomolybdic-phosphotungstic acid reagents. Amer. J. Enol. Viticul, 16:144158.

Somogyi, M., 1952. J. Biol. Chem., 200: 245.

Subhadrabandhu, S., and Nontaswatsri C., 1997. Combining ability analysis of some characters of introduced and local papaya cultivars. Sci. Hort., 71: 203212.

Sudha, R., Balamohan, T.N., Soorianathasundaram, K., Manivannan, N. and Rabindrane, R., 2013. Evaluation of F2 intergeneric population of papaya (Carica papaya L.) for resistance to papaya ringspot virus (PRSV). Scientia Hort., 158:6874.

Suma, 1995. Breeding investigations in papaya (Carica papaya). Ph. D. Thesis. Tamil Nadu Agricultural University. Coimbatore.

\section{How to cite this article:}

Sunil Gowda, D.C., C. Vasugi and Dinesh, M.R. 2017. Genetic Variability and Correlation Studies in Intergeneric Hybrid Progenies of Papaya. Int.J.Curr.Microbiol.App.Sci. 6(10): 14591464. doi: https://doi.org/10.20546/ijcmas.2017.610.172 